materia medica must be followed in order to educate a good therapist, and the sooner our medical institutions make a requisite of this branch, the better it will be for patients treated by their graduates.

\section{ON THE PRESENT TENDENCY TOWARDS HIGHER STANDARDS OF PROFESSIONAL EDUCATION.}

ONE cannot but observe with pleasure, in the present general advance and spread of higher education, that this advance is affecting not only the institutions of higher learning themselves and the general population, but also the strictly professional or technical schools. And whilst I wish in this short paper to refer more especially to law and medicine, my remarks will apply also to other-perhapsit to all other-professions.

The medical education of this country has, deservedly enough, for many years been looked upon with little favor, and has ill stood the test of competition with the methods of other countries; but now we are observing a great change in this respect, and there is no doubt that before many years the degree of M.D. from an American university will be as valuable a certificate on its face as can anywhere be obtained. Medical courses of four years' duration are now being adopted, or have already been adopted, by the leading medical schools in the country. The requirements in preliminary education have also greatly increased, and one may hope that before long such subjects as botany and zoology may be added to the requirements of a good English and general education from the intending student of medicine. State legislation itself has not been idle, and we find in the State of New York, for example, that no person can practise medicine without undergoing an examination conducted by the State Board of Examiners. A requirement of preliminary education has also been added, and though as yet no more than an elementary education is required, we may hope for better things in future.

As regards the profession of law, the advance is perhaps even more marked; more marked, that is, as regards legal education, for we no not find that the advance in the requirements for admission to the bar has been so considerable as might be desired, though they have been by no means neglected. Three-year law-school courses, which not so long since were unheard of, have now become the rule rather than the exception; and even in those schools which still see fit to maintain a two-years' course for the degree of bachelor of laws, a graduate course has been commonly added. Towards the general extension of the study of law so as to include the Roman or Civil Law, the tendency is by no means general, caused no doubt by the non-requirement of this branch for admission to the legal profession. Some universities, indeed, in their college courses, offer instruction in this subject; but it must be remembered that the majority of law-students are not college graduates, and so the breadth of their legal knowledge will be measured by the instruction given in the law school, however the depth and extent of what subjects they do touch upon may be increased afterwards. Yale is, I believe, alone among the universities in this country which gives extended courses in the civil law, and encourages their study by the bestowal of a degree (that of D.C.L.); but even then the course is one taken by but few students, and, as the catalogue says, is intended for those who intend to be something more than practising lawyers. This is not as it should be, and we must look to the future for more general study of this subject, for without it law can hardly be taught as a science, for law is - and should be known as - a science.

Education preliminary to the study of law has also risen greatly. Latin is now a usual requirement, and we may doubtless soon see it a universal one.

The day is not far distant then, let us hope, when the title Doctor or Lawyer will in itself mean an educated man.

N. H.

\section{LETTERS TO THE EDITOR.}

** Correspondents are requested to be as brief as possible. The vorter's name is in all cases required as proof of good faith.

On request in advance, one hundred copies of the number containing his communication will be furnished free to any correspondent.

The editor will be glad to publish any queries consonant with the character of the journal.

The Elm-Leaf Beetle. Galeruca xanthomelæna Schr.

IN Science, No. 492, for July 8, 1892, Dr. C. V. Riley records the facts, that at Washington, D.C., the imagos from the first brood of larvæ of the above insect had already appeared, and that eggs from beetles of this summer brood had been obtained June 28. In a letter dated July 27 , Dr. Riley informs me that from these eggs larvæ had been obtained and that these larvæ were then pupating. Dr. Riley's observations are positive, and prove

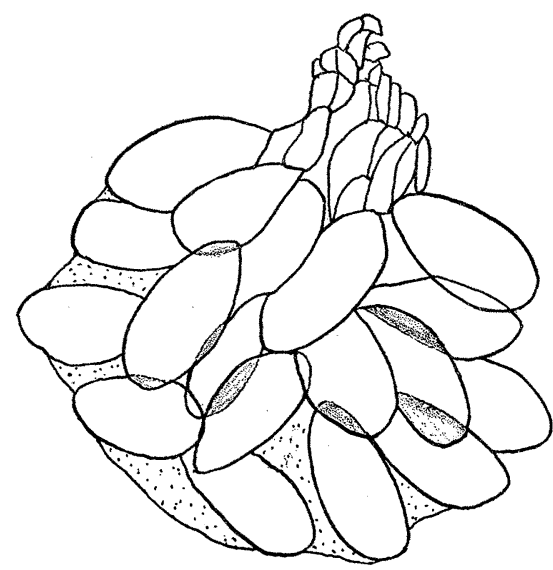

FIG. 1.

that there are two broods at least of this insect at Washington, D.C. They prove also that the beetles will mate and oviposit readily in confinement, and that there is only a brief interval between the appearance of the beetles and oviposition for the second brood of larvæ. This means that the beetles of both sexes are sexually mature when they emerge from the pupæ, or that they mature very rapidly and copulate within a very brief period after assuming the imaginal form. The accuracy of these observations I do not question; but neither do I admit that I am in error in claiming that in New Jersey, north of New Brunswick, there is only a single brood of this insect.

My acquaintance with the beetle at New Brunswick began in 1889 , in which year I protected the large number of elms in and near the college campus and about the Experiment Station by spraying with a London purple mixture. In the Report of the College Experiment Station for 1888, Dr. George D. Hulst, my predecessor in office, had stated that there were two broods of the insect annually; and on the appearance of the summer brood of beetles, I made ready to spray again as soon as the second brood of larvæ should begin to appear on the protected trees. They never did make their appearance, and I was unable to find a second brood on any other trees in the city. Dr. Hulst, in response to questions, informed me that he had noticed only one brood of larvæ in 1888; but there had been a cyclonic storm about the time they became mature, which freed the trees and covered the ground beneath them with thousands of the slugs, only a few of which ever found their way back to their food. 
To this destruction he attributed the absence of the second brood which published accounts led him to expect. I recorded these facts in my Report for 1889, claiming positively that there was a single brood only at New Brunswick. My observations, carefully repeated in 1890 and 1891, simply confirmed this conclusion.

These observations were presented at a meeting of the Entomological Club of the A. A. A. S., and, though he could not gainsay my facts, Dr. Riley yet doubted the correctness of my conclusion, as his parer in Science also shows. I therefore resolved to repeat my work yet more carefully in 1892 and to make it conclusive if

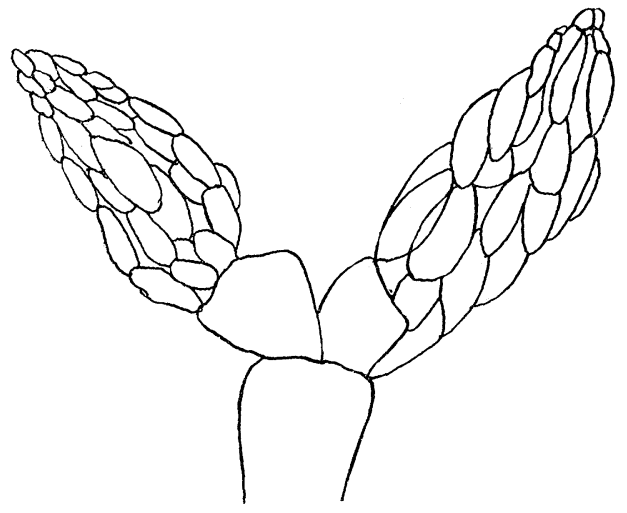

FIG. 2.

possible. The first signs of the beetles were noticed on May 17, in the form of small round holes eaten in a few leaves; on the 19th a few of the beetles were seen, and after that date they increased rapidly in numbers for some time. The weather for a few days was cold and wet, the insects were sluggish, and no eggs were observed until May 29. For special observation I selected a small tree between my home and the laboratory, which I passed several times daily, could see all parts of easily, and which was a prime favorite with the insects.

Eggs began hatching June 6, while yet oviposition continued. After the middle of the month the hibernating beetles diminished in number, and on the 30th not a beetle could be found. June 29 the first pupæ were formed and larvæ matured daily thereafter

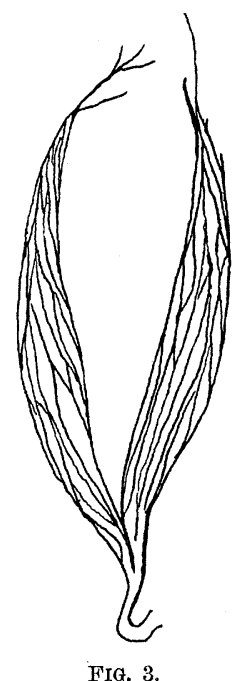

in greater abundance. At this date a very few unhatched eggclusters were yet to be found, but of those collected, only one mass gave larvæ July 1 . Since that date and up to date of writing (Aug. 1), there has not been a cluster of eggs on any tree that I have examined, and I have closely scanned many dozens, large and small. Early in July I gathered in over 200 pupæ and mature larvæ under the observed tree, and placed them in breeding-cages and jars Adults began to appear July 8, and very rapidly thereafter in the open air as well as in my cages. It is interesting to note that on June 29, when I secured the first pupa, Dr. Riley already had eggs of a second brood. The beetles bred by me fed readily and abundantly for nearly three weeks, and then more slowly, until at this time they refuse to feed entirely. During all this time there has not been a copulation nor an egg-mass in any jar, nor have I observed a copulation or an egg-mass in the open air. On July $30 \mathrm{I}$ observed a disposition on the part of my insects to refuse food and to hide among the dry leaves. I therefore selected a considerable number of them of both sexes for examination. In all, the sexual structures were immature or undeveloped. In the male it was difficult to get the testes, because they were mere empty thread-like tubes. In the females the ovaries were mere bundles of tubes without even partially-developed eggs. I gathered rather more than forty specimens from the trees, and found the same state of affairs, except that in one specimen the ova had begun to develop. This morning $I$ selected a few fresh and fat specimens - all females, as it proved - and though the abdomen was much distended, the distension was caused by the fully-dilated crop and stomach, and the ovaries were yet less developed than in any previously examined. Soon after the beetles appeared in May, I examined a number of them and found that in all the sexual structures were fully matured. In the males the testes were quite rigid coils, which were easily removed entire, while in the females the ovaries so completely filled the abdominal cavity that it was impossible to open it without detaching or crushing some of the eggs. The beetles earliest matured are now seeking winter quarters.

I consider my observations, now carried on for four years in succession, as conclusive of the fact that at New Brunswick, N.J., there is only a single brood of this species annually. I present herewith figures of part of one ovary (Fig. 1) of a beetle taken May 25, in which the oviduct and part of the developed eggs are removed; of the ovaries of a beetle taken July 30 on the trees, in which they were best developed of all those examined (Fig. 2); and of the ovaries of a specimen three weeks old (Fig. 3), with which all the others thai were examined agreed in that they were at least no more developed. All the figures were made by the use of a camera with a Zentmayer binocular stand, 2-inch objective, $a$ eye-piece, and drawing-board six inches from camera. The vagina is not shown in Fig. 3, but is as large as that shown at the base of Fig 2, and this is the only structure that has the full size. I have not considered it necessary to figure the male organs, though the difference between spring and summer beetles is equally striking. In none that I examined did I find anything like a developed testicle.

Rutgers College, Aug. 1.

John B. SMith, Sc.D.

\section{Wheat Rust and Smut.}

As a general rule the Bulletins issued from the various State Agricultural Experiment Stations, while not notable for the amount of original matter they contain, are fairly accurate in their statements, and their recommendations are to be relied upon. Occasionally errors creep in, some of them the result of haste in compilation, others the result of not being conversant with the latest information on the subjects discussed. In the former category must be placed the statement made in Bulletin No. 83 of the Michigan Agricultural Experiment Station that wheat rust can be successfully treated by what is known as the Jensen hot-water method; that is, immersing the seed in water having a temperature between $132^{\circ}$ and $135^{\circ} \mathrm{F}$. Wheat rust has been long under investigation. It has caused a loss of about $\$ 2,000,000$ sterling annually in Australia, and it is safe to say that there is not a country or a State where wheat is grown that has not suffered from its ravages. The fact is that while wheat rust is described and illustrated in the Bulletin in question, the treatment for prevention of wheat smut is given. It is needless to say that what s applicable to one is not to the other. Farmers who expect to prevent wheat rust by the hot-water treatment will be sorely disappointed. Perhaps their disappointment will result in making them question, without cause, however, the benefits to be derived from treating for smut. Between the two diseases there is a vast difference; one (rust) attacks the leaves, the other (smut) attacks the grain. In the latter case treatment of seed will be 